Environment Conservation Journal 15(1 \& 2) 99-107, 2014

ISSN 0972-3099 (Print) 2278-5124 (Online)

Abstracted and Indexed

\title{
Analysis of heavy metals and coliform in samples of drinking water collected from municipal ward offices of western suburbs of Mumbai, India
}

\section{Zodape G.V}

Received: 12.09.2013
Revised: 22.01.2014

Accepted: 19.02.2014

\begin{abstract}
14 drinking water samples were collected from Vile Parle to Dadar of Suburban's of (P-South ward offices of B.M.C (Bombay Municipal Corporation) Mumbai in the month from June to December 2012. The samples of drinking-water were analyzed for $\mathrm{Cu}, \mathrm{Zn}, \mathrm{Mn}, \mathrm{Fe}, \mathrm{As}, \mathrm{Cr}, \mathrm{Ni}, \mathrm{Pb}, \mathrm{Cd}$ and $\mathrm{Hg}$. From the results so obtained, the contamination due to heavy metals - Zn (3.115 ppm and 7.816 ppm), Mn (3.115 ppm and 7.426 ppm), Fe (1.124 ppm and 2.872 ppm), As (0.011 ppm to $0.091 \mathrm{ppm}), \mathrm{Cr}(0.188 \mathrm{ppm}$ and $0.998 \mathrm{ppm}), \mathrm{Pb}(1.587 \mathrm{ppm}$ and $4.56 \mathrm{ppm})$ and $\mathrm{Cd}(0.011 \mathrm{ppm}$ and $0.051 \mathrm{ppm})$ was found to be high whereas the contamination due to $\mathrm{Cu}(0.012 \mathrm{ppm}$ and $0.313 \mathrm{ppm})$, $\mathrm{Ni}(0.126 \mathrm{ppm}$ and $0.774 \mathrm{ppm})$, were found below the acceptable limits and no $\mathrm{Hg}$ was detected in the samples of drinking-water. In the present work, MacConkey Broth was used as a differential medium for detection and enumeration of coliforms from a wide variety water samples. The presence of positive doubtful presumptive test immediately suggests that the water is non potable (i.e., both acid and gas develops in a tube after 48 hours incubation). Confirmation suggests that there is fecal contamination in the water under investigation and hence it is non potable. All the fourteen samples (streaked from positive Ma cConkey broth tubes) were found to be contaminated with $E$. coli, which was further confirmed by the presence of colonies with green metallic sheen observed under a microscope confirmed that the said samples were contaminated with $E$. coli - the major indicator of fecal contamination.
\end{abstract}

Keywords: Coliform, drinking water, E. coli, heavy metals, Mac Conkey broth, municipal ward

\section{Introduction}

Water-related diseases are responsible for $80 \%$ of all illnesses/deaths in developing countries, and they kill more than 5 million people every year (WHO, 1995) (UNESCO, 2007). Water, the precious gift of nature to human being is being polluted day by day with increasing urbanization. Although three-fourth part of earth is surrounded by water but a very small portion of it can be used for drinking purposes. Ground water is an important source of drinking water for humankind. It contains over $90 \%$ of the fresh water resources and it is an important reserve of good quality water. Ground water, like any other water resource, is not just concerned with public health but is also of economic value (Armon and Kitty 1994). Water is one of the essentials that supports all forms of plant and animal life (Vanloon and Duffy, 2005) and it is generally obtained from two principal natural sources: Surface water such as fresh water from lakes, rivers, streams, etc. and Ground water such

\section{Author's Address}

Departments of Zoology, S.S. \& L.S. Patkar College of Arts and Science \& V.P. Varde College of Commerce and Economics, S.V. Road, Goregaon (West), Mumbai Email: gautamvz5@yahoo.com borehole water and well water (McMurry and Fay, 2004; Mendie, 2005). Water is not pure as it acquires contaminants from its surrounding and those arising from humans and animals as well as other biological activities (Mendie, 2005). The water pollution by heavy metals has become a question of considerable public and scientific concern in the light of the evidence of their toxicity to human health and biological systems (Anazawa et al., 2004). Heavy metals receive particular concern considering their strong toxicity even at low concentrations (Marcovecchio et al., 2007). They exist in water in colloidal, particulate and dissolved phases (Adepoju - Bello and Alabi, 2009) with their occurrence in water bodies being either of natural origin (e.g. eroded minerals within sediments, leaching of ore deposits and volcanism extruded products) or of anthropogenic origin (i.e. solid waste disposal , industrial or domestic effluents) (Marcovecchio et al., 2007).

The ever increasing human population and industrialization has resulted in tremendous build up of organics in many forms in water. Many unexpected organics are reported to be found even 
in remote parts like hills of Himalayas, Alaska and North Pole due to man-made devastation of our environment. The environmental education has aroused much awareness about the toxicity of traces of environmental pollutants in general and organics in particular.Internationally several organizations namely Food and Agriculture Organization FAO (1983), APHA: (1992), US Environmental Protection Agency (EPA) (2000), US Public Health Services (USPHS) (1991). The National Academy of Sciences (NAS) (1999), USA, etc. have worked on toxicity levels that can influence the human beings on short and long term basis and correlated corresponding symptoms chronic effects and diseases observed. The contaminants contributed in water, have also been reported along with toxicity tests. At present the population of Mumbai is severally suffering from lots of disorders particularly respiratory and digestive, due to air and drinking waters. Most of these causes have been identified and remedial measures have been taken up. However, toxic effect due to contamination of drinking waters, of the population of Mumbai is not primarily addressed and completely neglected. In fact the relevant toxic effect may be already prevalent in the society and most probably they may become severe in due course of time. Hence, the stage has already reached to address the problem in detail and to dig the thought under the problem.It is therefore necessary to determine the extent of contaminants in the water so that the warning signals can be given to the society in case the threshold limits have reached. Even otherwise it becomes necessary to educate the society of the social evils of pollution. The study can also provide the information on possible causes of pollution. So that mitigation measures to minimize provide the information on possible causes of pollution. So that mitigation measures to minimize the pollution can be taken in time.

\section{Material and methods}

\section{a) Sample Collection}

14 drinking water samples were collected from (Vile Parle west and east; Santacruz west and east; Khar west and east; Bandra west and east; Mahim west and east; Matunga west and east and Dadar west and east) P-South ward offices of B.M.C (Bombay Municipal Corporation) from Suburban's of Mumbai in the month from June to December 2012. The water samples were collected in propylene bottles and were stored at $-20{ }^{0} \mathrm{C}$ in freezer in the Department of Zoology, S.S \& L.S. Patkar College, Goregaon (West) Mumbai for further treatment.

\section{b) Sample Treatment}

The water samples were well mixed with $2 \mathrm{ml}$ concentrated $\mathrm{HNO}_{3}$ per liter sample and capped tightly until they were ready for analysis as proposed by (Ehi-Eromosele and Okiei, 2012)

\section{c) Preparation of MacConkey Broth:}

Ma cConkey Broth was used as a differential medium for detection and enumeration of coliforms from a wide variety water samples.

d) Preparation of standard metal ion solutions:

Stock solutions $(1 \mu \mathrm{g} / \mathrm{ml})$ of each of the metal ions were prepared using appropriate metal salt of AR grade quality in dilute hydrochloric acid. The working standards of these solutions were prepared by appropriate dilutions in distilled water.

\section{e) Instrumentation:}

The samples were analyzed on Inductively Coupled Plasma Atomic Emissions Spectroscopy (ICP-AES, Model ARCOS from M/s. Spectro, Germany) at the Sophisticated Analytical Instrument Facility (RSIC), Indian Institute of Technology (IIT) Powai, Mumbai-400076, India.

\section{d) Chemicals and Reagents:}

All the chemicals and reagents were procured from S.D. Fine Chemicals and Himedia were of AR grade quality

\section{Results and discussion}

Contamination of drinking water with high level of copper may lead to chronic anemia (Acharya et al., 2008). Studies have shown that ingesting copper may also be implicated in coronary heart diseases and high blood pressure, although coronary heart diseases have also been linked to copper deficiency. High levels of copper in drinking water can cause vomiting, abdominal pain, nausea, diarrhea. Darthmouth, (2001) has reported that copper leached into drinking water from copper pipes and described that just as little copper is essential for good health $(0.01 \mathrm{mg} / \mathrm{l})$, too much can be harmful. Ingesting large amounts of copper compounds (such as copper sulphate) can cause death by nervous system, liver and kidney failure. 
Table 1. Concentration of metal ions in drinking drinking water samples obtained from ward offices of B.M.C (Bombay Municipal Corporation) from Vile Parle to Dadar of Suburban's of Mumbai.

\begin{tabular}{|l|l|l|l|l|l|l|l|l|l|l|l|}
\hline S.NO & Sample & $\begin{array}{l}\mathbf{C u} \\
\mathbf{P p m} \\
\mathbf{N = 3}\end{array}$ & $\begin{array}{l}\mathbf{Z n} \\
\mathbf{P p m} \\
\mathbf{N = 3}\end{array}$ & $\begin{array}{l}\mathbf{M n} \\
\mathbf{P p m} \\
\mathbf{N = 3}\end{array}$ & $\begin{array}{l}\mathbf{F e} \\
\mathbf{P p m} \\
\mathbf{N = 3}\end{array}$ & $\begin{array}{l}\text { As } \\
\mathbf{p p m} \\
\mathbf{N = 3}\end{array}$ & $\begin{array}{l}\mathbf{C r} \\
\mathbf{p p m} \\
\mathbf{N = 3}\end{array}$ & $\begin{array}{l}\mathbf{N i} \\
\mathbf{p p m} \\
\mathbf{N = 3}\end{array}$ & $\begin{array}{l}\mathbf{P b} \\
\mathbf{p p m} \\
\mathbf{N = 3}\end{array}$ & $\begin{array}{l}\mathbf{C d} \\
\mathbf{p p m} \\
\mathbf{N = 3}\end{array}$ & $\begin{array}{l}\text { Hg } \\
\mathbf{p p m} \\
\mathbf{N = 3}\end{array}$ \\
\hline 1 & Vile Parle (W) & 0.230 & 6.221 & 5.344 & 1.186 & 0.022 & 0.971 & 0.153 & 1.606 & 0.011 & ND \\
\hline 2 & Vile Parle (E) & 0.216 & 3.237 & 5.136 & 1.277 & 0.034 & 0.188 & 0.126 & 2.588 & 0.029 & ND \\
\hline 3 & Santacruz (W) & 0.207 & 5.512 & 5.214 & 1.322 & 0.054 & 0.598 & 0.234 & 1.626 & 0.038 & ND \\
\hline 4 & Santacruz (E) & 0.311 & 4.155 & 6.145 & 1.798 & 0.074 & 0.527 & 0.276 & 3.565 & 0.024 & ND \\
\hline 5 & Khar(W) & 0.243 & 7.816 & 7.426 & 1.489 & 0.064 & 0.664 & 0.498 & 2.584 & 0.029 & ND \\
\hline 6 & Khar(E) & 0.205 & 7.264 & 3.115 & 1.284 & 0.087 & 0.719 & 0.187 & 1.618 & 0.031 & ND \\
\hline 7 & Bandra(W) & 0.199 & 6.143 & 6.352 & 1.453 & 0.032 & 0.624 & 0.711 & 1.585 & 0.024 & ND \\
\hline 8 & Bandra(E) & 0.207 & 4.186 & 5.139 & 2.872 & 0.023 & 0.892 & 0.676 & 3.667 & 0.021 & ND \\
\hline 9 & Mahim(W) & 0.243 & 4.515 & 6.115 & 1.376 & 0.053 & 0.979 & 0.487 & 4.56 & 0.018 & ND \\
\hline 10 & Mahim(E) & 0.207 & 3.434 & 5.131 & 1.552 & 0.062 & 0.675 & 0.143 & 2.525 & 0.031 & ND \\
\hline 11 & Matunga(W) & 0.311 & 2.231 & 4.309 & 1.787 & 0.091 & 0.973 & 0.213 & 2.604 & 0.029 & ND \\
\hline 12 & Matunga(E) & 0.216 & 5.354 & 4.214 & 1.628 & 0.012 & 0.321 & 0.432 & 3.514 & 0.039 & ND \\
\hline 13 & Dadar(W) & 0.313 & 7.155 & 5.127 & 1.124 & 0.028 & 0.324 & 0.621 & 2.628 & 0.017 & ND \\
\hline 14 & Dadar(E) & 0.112 & 6.312 & 7.338 & 1.259 & 0.011 & 0.998 & 0.774 & 1.587 & 0.051 & ND \\
\hline
\end{tabular}

Total reading taken $=\mathrm{N}$ (Average reading $=3$ )

$\mathrm{ND}=$ less than $0.001 \mathrm{ppm}$

Table 2. Determination of MPN (Coliform) in drinking drinking water samples obtained from ward offices of B.M.C (Bombay Municipal Corporation) from Vile Parle to Dadar of Suburban's of Mumbai.

\begin{tabular}{|c|c|c|c|c|c|c|}
\hline S. No & Water Sa & & $\begin{array}{l}\text { No. of tubes showing } \\
\text { Positive test }(10 \mathrm{ml}) \\
\mathrm{N}=3\end{array}$ & $\begin{array}{l}\text { No. of tubes showing } \\
\text { Positive test (1ml) } \\
\text { N=3 }\end{array}$ & $\begin{array}{l}\text { No. of tubes showing } \\
\text { Positive test }(0.1 \mathrm{ml}) \\
\mathrm{N}=3\end{array}$ & $\begin{array}{l}\text { MPN } \\
/ 100 \mathrm{ml}\end{array}$ \\
\hline \multirow[t]{2}{*}{1} & \multirow{2}{*}{ Vile Parle } & $1 \mathrm{~W}$ & 03 & 02 & 01 & 17 \\
\hline & & $2 \mathrm{E}$ & 03 & 02 & 00 & 14 \\
\hline \multirow[t]{2}{*}{2} & \multirow[t]{2}{*}{ Santacruz } & $3 \mathrm{~W}$ & 02 & 01 & 01 & 09 \\
\hline & & $4 \mathrm{E}$ & 02 & 01 & 01 & 09 \\
\hline \multirow[t]{2}{*}{3} & \multirow[t]{2}{*}{ Khar } & $5 \mathrm{~W}$ & 01 & 01 & 00 & 06 \\
\hline & & $6 \mathrm{E}$ & 01 & 01 & 00 & 06 \\
\hline \multirow[t]{2}{*}{4} & \multirow{2}{*}{ Bandra } & $7 \mathrm{~W}$ & 04 & 04 & 00 & 34 \\
\hline & & $8 \mathrm{E}$ & 04 & 04 & 00 & 34 \\
\hline \multirow[t]{2}{*}{5} & \multirow[t]{2}{*}{ Mahim } & $9 \mathrm{~W}$ & 02 & 03 & 00 & 12 \\
\hline & & $10 \mathrm{E}$ & 03 & 02 & 00 & 14 \\
\hline \multirow[t]{2}{*}{6} & \multirow[t]{2}{*}{ Matunga } & $11 \mathrm{~W}$ & 02 & 00 & 01 & 07 \\
\hline & & $12 \mathrm{E}$ & 04 & 03 & 00 & 27 \\
\hline \multirow[t]{2}{*}{7} & \multirow[t]{2}{*}{ Dadar } & 13W & 04 & 04 & 00 & 34 \\
\hline & & $14 \mathrm{E}$ & 04 & 04 & 00 & 34 \\
\hline
\end{tabular}

(Note: With presumptive test both acid and gas formation is taken as positive)

Average readings $=\mathrm{N}=3$

$\mathrm{W}=$ west

$\mathrm{E}=$ east

MPN= Most probable number of Coli form

W.H.O (World Health Organization).1993

Satisfactory quality $=05$ bacteria $/ \mathrm{L}$ of water

Drinking water $=03$ or less bacteria $/ \mathrm{L}$ ofwater

Polluted = 100 bacteria / $\mathrm{L}$ of water

Slightly polluted $=10$ bacteria $/ \mathrm{L}$ of water

Heavily polluted $=10000$ bacteria $/ \mathrm{L}$ of water
The effect of heavy metal concentration which was higher in untreated sewage water of Musi river near Hydrabad, India was studied by Raj et al (2006). The distribution and characterization of heavy metals in water in Jeedimetla industrial area in Andhra Pradesh showed concentration of $\mathrm{Cu}(4.2$ $13.7 \mathrm{ppb})$, the concentration of this element was found to be far above the permissible level in water (Govil, 2001). The estimated mean concentration of 
$\mathrm{Cu}$ was $0.500 \mathrm{ppm}$, in regions around a fertilizer factory in Punjab (Dey et al, 1997) was found below the permissible limits. Water sample in industrially polluted areas in Bangalore, Karnataka, India had higher concentration of $\mathrm{Cu} 33.63 \mathrm{ppm}$ (Gowda et al., 2003). Monitoring and assessing the heavy metal like $\mathrm{Cu}$ contents in the industrial effluents from Ambanath area in Maharashtra state India, revealed that $\mathrm{Cu}$ concentration varied from 80 to $10.2 \mathrm{ppm}$ which is above the specified maximum acceptable concentration $(1.0 \mathrm{mg} / \mathrm{l})$ (Lokhande \& Sathe, 2001). Tuzen and Soylak, (2006), evaluated the lowest and highest values of copper in Resadiye and Erbaa. In the present work, the lowest and highest mean concentrations of copper are $0.012 \mathrm{ppm}$ and $0.313 \mathrm{ppm}$ respectively. None of the water samples contained copper above the specified maximum acceptable concentration as prescribed by (1.0 ppm) WHO (1998). The main industrial uses of zinc are galvanization and preparation of alloys. It is believed that galvanized pipes, through which water is supplied to various places, is the source of zinc in natural waters including drinking water. Gowda et al. (2003) found that the levels of zinc in the water samples obtained from industrially polluted areas in Bangalore, India, were higher (41.09 ppm) than the limit prescribed by WHO, (1998). The mean level of zinc in drinking water samples in drinking water from Xian, China has been reported as $21.84 \mu \mathrm{g} / \mathrm{l}$ (Guo et al., 2004) and that from Tehran, Iran, has been reported as $220 \mathrm{ug} / \mathrm{l}$ (Yamini et al., 2004). It has been reported that the concentrations of zinc ranged from $0.086 \mathrm{ppm}$ to $0.163 \mathrm{ppm}$ in samples of drinking water obtained from the surface water level of lower lake in Bhopal, India. These values are lower than the value prescribed by WHO, (1998) (Gupta et al., 2005).In the present work, the lowest and highest mean concentrations of zinc are $3.115 \mathrm{ppm}$ and $7.816 \mathrm{ppm}$ respectively. Thus, the highest mean concentration of zinc is found to be higher than the $(5.0 \mathrm{ppm})$ WHO, (1998) standard.Manganese is a mineral that is required in small amounts in the human body, and it is present in enzymes like oxidoreductases, transferases, hydrolases, lyases, isomerases, and ligases (Oga, 2008; Goldberg 1975) which are necessary for several biological functions. Manganese is involved in the function of numerous organ systems and is needed for normal immune function, regulation of blood sugars production of cellular energy, reproduction, digestion, and bone growth. Manganese works with vitamin $\mathrm{K}$ to support clotting of the blood and is considered necessary for various biological functions (Goldberg 1975). The effect of heavy metal concentration which was higher in untreated sewage water of Musi river near Hydrabad, India was studied by Raj et al., (2006). Sewage water collected all along the Musi river at different sites was contaminated with $\mathrm{Ni}$, with mean concentration of $0.21 \mathrm{ppm}$ respectively. Almost all the manganese concentration fell within the standard limit (0.05 $\mathrm{ppm})$, which varied from $0.05 \mathrm{ppm}$ to $0.00 \mathrm{ppm}$ from all areas except one sample from Heliopolice with $0.1 \mathrm{ppm}$ (Hanaa et al., 2000).In the present work, the lowest and highest mean concentrations of $\mathrm{Mn}$ are $3.115 \mathrm{ppm}$ and $7.426 \mathrm{ppm}$ respectively. Thus, the lowest and highest mean concentration of $\mathrm{Mn}$ is found to be above the (0.05 ppm) WHO 1998 standard.Iron in drinking water is present as $\mathrm{Fe}^{2}+$ and $\mathrm{Fe}^{3}+$ in suspended form (Sonawane, 2003). Drinking water containing iron above $1.00 \mathrm{mg} / \mathrm{l}$ is not considered to be suitable for drinking purposes. As per the standards set by WHO, the permissible level of iron is $0.3 \mathrm{ppm}$. Above $1.00 \mathrm{ppm}$ of iron in drinking water is not considered to be suitable for drinking purposes WHO. 1993. In North-East region of India, the amount of iron is relatively high and almost all states of India contain iron above the permissible limit. While the lowest iron level was found in water samples obtained from Niksar $(14.5 \pm 0.1 \mathrm{ppm})$, the highest iron concentration was found in water samples obtained from Resadiye (34.6 $\pm 0.3 \mathrm{ppm})$. WHO has proposed a guideline value of $0.3 \mathrm{ppm}$ for drinking-water (Singh, 2006). In the present work the lowest and highest mean concentration of iron are $1.124 \mathrm{ppm}$ and $2.872 \mathrm{ppm}$ respectively, the upper tolerable limit of iron being above the permissible limit as prescribed by WHO. The main forms of human exposure to arsenic are ingestion and inhalation. The main source of contamination of drinking-water is the naturally occurring arsenic in groundwater. Some of the countries that have such extensive naturally occurring arsenic in groundwater and hence, potentially in drinking water include - India (especially in Bengal), Bangladesh, Nepal, Thailand, China, Mongolia, Tibet, Vietnam, Laos, Cambodia, Myanmar, various South American 
countries and areas in North America and Western Australia (Michael et al., 2001).The arsenic concentration was found to be a major threat in northeast states of India. It has been reported that arsenic concentration in groundwater exceeds the permissible level $(50 \mu \mathrm{g} / \mathrm{l})$ in Assam, Arunachal Pradesh, Nagaland, Manipur and Tripura states, Arunachal Pradesh.Arsenic concentration was found to be higher in the area adjacent to foothills bounded by Himalayan mountains. The concentration of arsenic was relatively high in shallow tubewell (15- $40 \mathrm{~m}$ deep) as compared to deep tube well and rings-well (Singh, 2004). In the present work, the values of the mean minimum and maximum concentrations of arsenic in the drinkingwater samples are found to be $0.011 \mathrm{ppm}$ to 0.091 ppm respectively. These values are above the limit prescribed WHO 1993.Chromium is essential to animals and human. Chromium in excess amounts can be toxic especially the hexavalent form. Chromium is used in metal alloys and pigments for paints, cement, paper, rubber, and other materials. Electroplating can release chromic acid spray and air-borne Cr-trioxide, both can result in direct damage to skin and lungs (Grounse, et al., 1983) as well as chromium dust has been considered as a potential cause of lung cancer (Hyodo, et al., 1980). Sub chronic and chronic exposure to chromic acid can cause dermatitis and ulceration of the skin (U.S.EPA, 1999). Long-term exposure can cause kidney and liver damage, and damage too circulatory and nerve tissue. Chromium often accumulates in aquatic life, adding also to the danger eating fish that may have been exposed to high levels of chromium. The lowest and highest concentration of $\mathrm{Cr}$ was obtained by Roberto et al., (2008) in drinking water i.e. was $0.06 \mathrm{mg} \mathrm{l}^{-1}$, to $0.08 \mathrm{mg} \mathrm{l}^{-1}$.In the present work, the values of the mean minimum and maximum concentrations of $\mathrm{Cr}$ in the drinking water samples are found to be 0.188 ppm and $0.998 \mathrm{ppm}$ respectively. These values are above the limit prescribed WHO 1993. Nickel is used as alloys product, nickel-plating for anticorrosion and in the manufacture of batteries. It is regarded as an essential trace metal but toxic in large amount to human health. It is considered as carcinogenic to human. Ambrose et al. (1976) reported that high-dose of nickel in rats and dogs were significantly decreasing their body weights.Hanaa et al., (2000) reported highest nickel concentrations from El-Salam and the lowest from El-Mataria areas and El-Marg which were 1.42 ppm, $1.42 \mathrm{ppm}$ and $0.05 \mathrm{ppm}$ respectively In the present work, the values of the mean minimum and maximum concentrations of lead in the drinking water samples are found to be $0.126 \mathrm{ppm}$ and 0.774 ppm respectively. These values are below the limit prescribed WHO $1993 . \quad$ Lead is a commulative poison and a possible human carcinogen (Bakare, 2005). It is a neurotoxin and is responsible for the most common type of human metal toxicosis (Berman, 1980). Also, studies have linked lead exposures even at low levels with an increase in blood pressure (Zietz et al., 2007) as well as with reduced intelligence quotient in children (Needleman, 1993) and with attention disorders (Yule and Rutter, 1985). The possible long term effects of chronic exposure to lead present in drinking water are subject to considerable public concern (Zietz et al., 2007). Some of the common sources of lead poisoning are from lead paints, utensils made of lead containing alloys and tetraethyl lead, used as an anti-knock agent in motor fuel. The lead compounds carried into the air as fumes of lead oxide and lead bromide (from motor exhaust) ultimately settle in the field and through food and drinks enter human body

(Banerjea, 1995). Adepoju and Alabi (2005), carried out the analysis of 10 samples of well-water and 19 samples of borehole-water and found maximum contaminant level $(0.01 \mathrm{mg} / \mathrm{l})$ with the maximum concentration detected being 0.024 $\mathrm{mg} / \mathrm{l}$.These results are of concern as lead has been recognized for centuries as a cumulative general metabolic poison. Bakir et al., (2003) found that lead contents of the water samples investigated from Tokat city were below $5 \mu \mathrm{g} / \mathrm{l}$ and this level of lead is below the limit prescribed $0.01 \mathrm{mg} / \mathrm{l}$ by WHO (1993). In the present work, the values of the mean minimum and maximum concentrations of lead in the drinking water samples are found to be $1.587 \mathrm{ppm}$ and $4.56 \mathrm{ppm}$ respectively. These values are above the limit prescribed WHO 1993. Cadmium is extremely toxic even in low concentrations, and will bio-accumulate in organisms and eco-systems and it has a long biological half-life in the human body, ranging from 10 to 33 years (Es' haghi et al., 2011). Cadmium is considered as one of the priority pollutants from monitoring in most countries and 


\section{G.V Zodape}

international organizations. Cadmium can produce coughing, headaches, and vomiting. In larger doses, cadmium can accumulate in the liver and kidneys, and can replace calcium in bones, leading to painful bone disorders and to a renal failure Celik and Oehlenschlager (2007). The maximum level of Cd was observed in March with an average of 0.014 $\mathrm{mg} \mathrm{l}^{-1}$ while the concentration for the rest of the months was quite homogeneous Roberto et al., 2008. Momodu and Anyakora (2010). The effect of heavy metal concentration which was higher in untreated sewage water of Musi river near Hydrabad, India was studied by Raj et al (2006). The estimated mean concentration of Cd was 0.006 ppm, in regions around a fertilizer factory in Punjab (Dey et al, 1997). The cadmium water samples analyzed by Gowada et al., (2003) were found to be 0.05ppm Gupta et al., (2005) found 0.014 to 0.41 ppm and Hyodo, (2005) found 0.0045 to $0.013 \mathrm{ppm}$ in drinking waters.In the present work, the values of the mean minimum and maximum concentrations of cadmium in the drinking water samples are found to be $0.011 \mathrm{ppm}$ and $0.051 \mathrm{ppm}$ respectively. These values are above the limit prescribed WHO 1993.Naturally occurring mercury has been widely distributed by natural processes such as volcanic activity. Mercury finds use in industrial processes, in electrical appliances (lamps, mercury cells), in industrial and control instruments (thermometers, barometers), in laboratory apparatus and as a raw material for various mercury compounds. The latter are used as fungicides, antiseptics, preservatives, pharmaceuticals, electrodes and reagents. Mercury has also been widely used in dental amalgams. A less well characterized use is in ethnic and folk remedies, some of which can give rise to significant exposure of individuals (IPCS, 2003). Levels of mercury in rainwater are in the range 5-100 ng/litre, but mean levels as low as $1 \mathrm{ng} /$ litre has been reported (IPCS, 2003). Naturally occurring levels of mercury in groundwater and surface water are less than $0.5 \mu \mathrm{g} /$ litre. Ware, (1989) has reported that a small number of ground waters and shallow wells in the USA were shown to have mercury levels that exceeded the maximum contaminant level of $2 \mu \mathrm{g}$ /litre set by the US Environmental Protection Agency for drinking-water (2000). An increase in the mercury concentration up to $5.5 \mu \mathrm{g} /$ litre was reported for wells in Izu Oshima Island (Japan), where volcanic activity is frequent (Magara et al., 1989). In a contaminated lake system in Canada, methyl mercury was found to constitute a varying proportion of total mercury, depending on the lake (IPCS, 2003). There have been no reports of methyl mercury being found in drinking-water.In the present work, no mercury was detected in the drinking-water samples under investigation. It can therefore be concluded that, if at all mercury was present in the drinking-water samples, its content was less than $0.001 \mathrm{ppm}$ and hence not detected.

\section{MPN (Most probable Number)}

MacConkey Broth was used as a differential medium for detection and enumeration of coliforms from a wide variety water samples. The presence of positive doubtful presumptive test immediately suggests that the water is non potable (i.e., both acid and gas develops in a tube after 48 hours incubation). Confirmation of these results is the presumptive tests of result of coli form origin that is recognized as indicators of fecal contamination. With confirmed test all the fourteen samples (streaked from a positive Ma cConkey broth tubes from the presumptive test) were found to be contaminated with $E$. coli the major indicator of fecal contamination (presence of colonies with green metallic sheen). The presence of $E$. coli in the sample of drinking-water is a major health concern and call for remedial attention. The presence of this pathogen in the samples is an indication of the likely presence of other enteric pathogens suggesting that the samples of drinking-water are heavily contaminated with faecal matter (Petridis et al., 2002).The water supplied to the Mumbai city from the different lakes might not be free from contamination. The location of water-pipelines close to potential dumps containing wastes such as expired drugs, batteries, waste oils, synthetic detergents, disinfectants, human and animal wastes, etc. could lead to ground water pollution. Detergents and other chemicals released in water due to activities such as bathing, washing of clothes; etc. in the vicinity of the water body can pollute the groundwater with complex organic and inorganic chemicals. The location of waterpipelines close to drain-pipelines can cause faecal contamination. These contaminants may infiltrate into the lakes thereby constituting a serious health threat. Diseases such as diarrhea, meningitis, acute 
renal failure, urinary tract infections, and haemolytic anaemia have been known to result from consumption of such contaminated waters as described by (Petridis et al., 2002). In the present work, all the fourteen samples (streaked from positive MacConkey broth tubes) were found to be contaminated with E. coli, which was further confirmed by the presence of colonies with green metallic sheen observed under a microscope.

\section{Conclusion}

The 14 samples of drinking-water were randomly collected from Vile Parle to Dadar. From the results obtained, the contamination due to heavy metals $\mathrm{Zn}, \mathrm{Mn}, \mathrm{Fe}, \mathrm{As}, \mathrm{Cr}, \mathrm{Pb}$ and $\mathrm{Cd}$ was found to be high whereas the contamination due to $\mathrm{Cu}, \mathrm{Ni}$; was found below the acceptable limits and no $\mathrm{Hg}$ was detected in the samples of drinking-water. Therefore, it can be concluded that if excess of the elemental toxicants enter the human / animal body through drinking water, they can pose health hazards because of their cumulative effect in the body. In view of these findings, the lakes which supply the drinking water to the Mumbai city should be monitored periodically to avoid excessive intake of trace metals by human, and to monitor the pollution of aquatic environment. Further, strict method of waste disposal control should be adopted to ensure the safety of the environment and to safeguard our aquatic life. As there is an indication of the presence of E. coli in all the samples, it has been concluded that the samples are contaminated and are not free from fecal contamination. The present reports however may eliminate the possibility of opportunistic pathogens in the water samples. There may be a possibility of contamination of ground water also and care should be taken to avoid the contact of water bodies with sewage drainage of water sources. The intermittent bacteriological analysis is needed to rule out the presence of opportunistic pathogens and recent fecal contamination if any.

\section{Acknowledgement}

Authors are thankful to the Director, Sophisticated analytical instrument facility (RSIC), Indian institute of technology (IIT) Powai, Mumbai400076, for providing facilities of (ICP-AES) Atomic absorption apectrophotometer (AAS) for the analysis of samples. Thanks are also due to the
Principal, S.S. \& L.S. Patkar College of Arts and Science \& V.P. Varde College of Commerce and Economics, S.V. Road, Goregaon (West), Mumbai400062.

\section{References}

Acharya, G.D. Hathi, M.V. Patel A.D and Parmar, K.C. 2008. Chemical Properties of Groundwater in Bhiloda Taluka Region, North Gujarat, India, E-J. Chem 5 (4) pp 792-796,

Adepoju-Bello, A.A. and O.M. Alabi 2005. Heavy metals: review. The Nig. J. Pharm., 37: 41-45.

Ambrose, A.M., D.S. Larson, J.R. Borzelleca and G.R. Hennigar 1976. Long-term toxicologic assessment of nickel in rats and dogs. J. Food Sci. Technol. 13: 181-187.

Anazawa K, Kaido, Y., Shinomura, Y., Tomiyasu T. and Sakamoto, H. 2004. Heavy-metal distribution in River waters and sediments around a "Fireflyillage'e, Shikoku Japan: Application of multivariate analysis. Analytical Sciences; (20):79-84.

APHA. 1992. Standard methods of examination of water and west water, American Public Health Association (Washington)

Armon R. and Kitty 1994. The Health Dimension of Groundwater contamination. In: Groundwater Contamination and Control, Holler (Ed.). Marcel Dekker, Inc., New York, USA.

Agency for toxic substances and disease registry (ATSDR). 2000. Toxicological Profile for Manganese, Agency for Toxic Substances and Disease Registry (ATSDR), Atlanta, Ga, USA,

Bakare-Odunola M.T. 2005. Determination of some metallic impurities present in soft drinks marketed in Nigeria. The Nig. J. Pharm.; 4(1): 51- 54.

Bakir, M.B., Hacim M.A. K., Gulec, M.M., Ozer, M.M. and Hasde, M. 2007.The quality of groundwater for certain chemicals in military fields in Ankara, Mil. Med, 168,

Berman, E. 2003. Toxic Metals and Their Analysis. Philadelphia, PA: Hayden and Sons. Chemical Safety (Environmental Health Criteria 101). Cornell University. http://www.mqtinfo.org/planningeduc0020.as p. 1980

Celik, U. and Oehlenschlager, J. 2007. High contents of cadmium, lead, zinc and copper in popular fishery products sold in Turkish supermarkets. Food Control, 18, 258-261.

Darthmouth, 2001. Toxic Metal Research Programme, A program of Centre for Environmental Health Scienceat Darthmouth. 
Dey S., Dwivedi S.K. and Swaraup D. 1997. Mineral deficiency in buffalo around a fertilizer factory. Indian $\boldsymbol{J}$. Animal Sci. 67: 780-781

D. Banerjea 1995. Some Aspects On The Role Of Metal Ions In Biological Systems, Everyman's Science, Vol. XXIX, No. 6 ,

Es-haghi, Z. Khalili, M. Khazaeifar A. and Rounaghi, G.H. 2011. Simultaneous extraction and determination of lead, cadmium and copper in rice samples by a new preconcentration technique: Hollow fiber solid phase microextraction combined with differential pulse anodic stripping voltammetry, Electrochimica Acta 56 (9), 31393146.

Ehi-Eromosele C. O. Okiei, W. O. 2012. Heavy Metal Assessment of Ground, Surface and Drinking Water Samples in Lagos Metropolis Using Anodic Stripping Voltammetry; Resources and Environment , 2(3): 82-86

FAO. 1983. Manual of methods of aquatic environment

Goldberg, E. D. 1975. The muscle watch- A first step in global marine monitoring. Marine Pollution Bulletin, 6: 111

Govil K.P. 2001. Distribution and characterization of heavy metals in Jeedimetla Industrial area Andhra Pradesh, India, Pollut. Res., 20: 245-255,

Gowda, N.K.S., Malathi V. S., Jash S. and Roy K.S. 2003. Status of pollutants and stress elements in water, soil, vegetation and dairy animals in industrial areas of Banglore, India. Indian J.Dairy Sci - 56: 86-90

Guo, Y., Din, B., Liu, Y., Chang, X., Men, G. S., Tian, M. 2004. Preconcentration of trace metals with 2 (methylthio) anilinefunctionalized XAD-2 and their determination by flame atomic absorption spectrometry. Anal. Chim. Acta, 504: 319

Grounse, R. G., Pories, W. J., Bray, J. T. and Mauger, R. L. 1983, Geochemistry and Man: Health and Diseases. In Thorton, I. 1983. Applied Environmental Geochemistry. Academic Press, London 267-303.

Gupta S. K., Savita D. and Tiwari M.S.S. 2005. Assessment of heavy metals in surface water of lower lake, Bhopal, India Pollut. Res., 24; 805 -808,

Hanaa, M., Salem, Eweida, A., Eweida and Azza, Farag 2000. Heavy metals in drinking water and their environmental impact on human health Cairo University, Egypt, page 542- 556,

Hyodo, K., Susuki, S., Furuya, N. and Meshiazuka, K. 1980. Archives of Occupational and Environmental Health 46, 141- 150 .

IPCS. 2003. Elemental mercury and inorganic mercury compounds: human health aspects. Geneva, World Health
Organization, International Programme on Chemical Safety (Concise International Chemical Assessment Document 50)

Lokhande, R.S and Sathe, C.N. 2001. Monitoring and assessment of heavy metals contents in the industrial effluents from Ambarnath M.I.D. C. area, Maharashtra. Pollut. Res., 20; 239 -243,

MacConkey, A. T., 1900. (Double strength) for the primary isolation of coliforms from large samples such as water and wastewater. The Lancet, ii: 20

MacConkey, A. T., 1905. Lactose-fermenting bacteria in feces. J. Hyg. 5:333-379.

Magara, Y. 1989. Effects of volcanic activity on heavy metal concentration in deep well water. In: Technical Papers, Water Nagoya '89; 7th Regional Conference and Exhibition of Asia-Pacific, Nagoya, Japan. International Water Supply Association, pp. 411-419,

Marcovecchio, J.E., Botte, S.E. and Freije, R.H. 2007. Heavy Metals, Major Metals, Trace Elements. In: Handbook of Water Analysis. L.M. Nollet, (Ed.). 2nd Edn. London: CRC Press; 275-311.

Momodu, M.A. and Anyakora, C.A. 2010. Heavy Metal Contamination of Ground Water: The Surulere Case Study Research Journal Environmental and Earth Sciences 2(1): 39-43

McMurry, J. and R.C. Fay 2004. Hydrogen, Oxygen and Water. In: McMurry Fay Chemistry. K.P. Hamann, (Ed.). 4th Edn. New Jersey: Pearson Education, pp: 575-599,

Mendie, U. 2005. The Nature of Water. In: The Theory and Practice of Clean Water Production for Domestic and Industrial Use. Lagos: Lacto-Medals Publishers, pp: 1-21.

Michael, Berg, Hong, Con, Tran, Thi, Chuyen, Nguyen, Hung Viet, Pham, Roland, Schertenlieb, Walter, Giger 2001. Arsenic contamination of groundwater and drinking water in Viet Nam: a human health threat, Environmental Science and Technology, vol. 35, no. 13, pp. 2621.6,

Needleman, H.L. 1993. The current status of childhood lowlevel lead toxicity. Neurotoxicology, 14: 161-166,

Oga, S. 2008. Fundamentos de Toxicologia, Atheneu Editora, Sao Paulo, Brazil,

Petridis, H. Kidder, G. and Ogram, A. 2002. A potential Health Concern E. coli 0157:H7; IFAS Extension, University of Florida, Gainesville. SL 146,

Raj, B.G., Patnaik, M.C., Babu, S.P., Kalakuman, B., Singh, M.V., Shylaja, J. 2006. Heavy metal contaminations in water- soil- plant- animal cont in uum due to pollution in Musi river around Hyderabad in India. Indian. J. Animal Sci. 76; 131-133, 
Roberto, Gutiérrez, L., Hector, Rubio-Arias1, Ray, Quintana, Juan, Angel Ortega and Melida Gutierrez 2008. Heavy metals in water of the San Pedro River in Chihuahua, Mexico and its potential health risk Int. J. Environ. Res. Public Health 5(2), 91-98,

Singh, A.K. 2006. Chemistry of arsenic in ground water of Ganges-Brahmputra river basin, India, Curr. Sci., 91(5), 17

Singh, A.K. 2004.Arsenic contamination in groundwater of North Eastern India. (Jain, C.K., Trivedi, R.C. and Sharma, K.D. (Eds.), Hydrology with focal theme on water quality (pp 255-262). Allied Publishers, New Delhi.

Sonawane V.Y. 2003. Detection of heavy metal ions in different samples of water near Pen-Khopoli (Maharashtra). Asian J. Chem., 15, 1880,

The National Academy of Sciences 1999. Arsenic in drinking water. National Academy Press, Washington, 1999. In: http://books.nap.edu/books/0309063337/html/1.html

Tuzen, M. Soylak, M. 2006. Evaluation of Metal Levels of Drinking Waters from the Tokat-Black Sea Region of Turkey Polish J. of Environ. Stud. Vol. 15, No. 6 915-919,

UNESCO. 2007. Water Portal newsletter. No. 161: Waterrelated Diseases. www.unesco.org/ water/news/newsletter /161.sht ml (accessed 03.01.08),

U.S. EPA (Environmental Protection Agency). 2000. Guidance for Assessing Chemical Contaminant Data for Use in Fish Advisories, V. 1: Fish Sampling and analysis. 3d Ed. Office of Science and Technology, Office of Water, Washington, DC, Chap. 1 pp. 1-22.

U.S. Public Health Service, 1991. Review of Fluoride: Benefits and Risks. Report of the subcommittee on fluoride of the Committee to Coordinate Environmental Health and
Related Programs. Washington, DC: Department of Health and Human Services. Public Health Service; Available at: www.health.gov/environment/ReviewofFluoride/default.ht m. Accessed June 9, 2008.

Vanloon, G.W. and S.J. 2005. Duffy the Hydrosphere. In: Environmental Chemistry: A Global Perspective. $2^{\text {nd }}$ Edn. New York: Oxford University Press, pp: 197-211,

Ware, G.W. ed. 1989. Mercury. USEPA Office of Drinking Water health advisories. Reviews of Environmental Contamination and Toxicology, 107:93-102.

WHO. 1993. Guidelines for Drinking Water Quality (2nd edn.) (Vol. 1-2) Recommendations, Geneva,

WHO. 1998. Guidelines for Drinking Water Quality (2nd edn.) (Vol. 2) Health Citeria and Other Supporting Information. World Health Organization, Geneva

World Health Organization. 1995. Guidelines for Drinking water Quality, World Health Organization, Geneva, Switzerland pp 121.

Yule, W. and M. Rutter 1985. Effect on Children's Behavior and Cognitive Performance: A Critical Review. In: Dietary and Environmental Lead $(\mathrm{Pb})$ : Human Health Effects. R. Mahaffey, (Ed.). New York: Elsevier, pp: 211-251,

Yamini, Y., Hosseini, M.H. Morsali A. 2004. 'Solid phase extraction and flame atomic absorption spectrometric determination of trace amounts of zinc and cobalt ions in water samples', Microchim acta , Vol. 146, No. 1, pp. 6772 ,

Zietz, B.P., J. Lap and R. Suchenwirth. 2007. Assessment and management of Drinking water Lead contamination in Lower Saxon, Germany. Int. J. Environ. Health Res., 17(6): 407-418, 